\title{
Freezing Experiment of Supercooled Water Droplets Frozen by Using Single Crystal Ice
}

\author{
By Hiroshi Uyeda and Katsuhiro Kikuchi \\ Department of Geophysics, Hokkaido University, Sapporo \\ (Manuscript received 4 July 1977)
}

\begin{abstract}
To investigate the temperature dependency of the angle between the $c$-axes of neighbouring crystals of frozen water droplets, supercooled water droplets of 0.6 to $1.0 \mathrm{~mm}$ in diameter were nucleated and frozen using single crystal frost ice in temperature ranges of -10 to $-15^{\circ} \mathrm{C},-15$ to $-20^{\circ} \mathrm{C}$ and -20 to $-25^{\circ} \mathrm{C}$. At the range of -15 to $-20^{\circ}$, the peak of the angles between the $c$-axes of neighbouring crystals was around $20^{\circ}$, on the other hand, there were two peaks around $20^{\circ}$ and $70^{\circ}$ at the temperature range of -20 to $-25^{\circ} \mathrm{C}$. The peak around $20^{\circ}$ obtained in the previous paper by authors (1976a) in the temperature range of -17 and $-23^{\circ} \mathrm{C}$ is considered to be affected by relatively warmer temperatures above $-20^{\circ} \mathrm{C}$. The peak around $70^{\circ}$ appeared at the temperature range of -20 to $-25^{\circ} \mathrm{C}$ in this experiment, strictly coincided with the results of observations in natural snow crystals grown at air temperatures below $-20^{\circ} \mathrm{C}$. At the temperature range of -10 to $-15^{\circ} \mathrm{C}$, almost all supercooled water droplets froze single crystals and the orientation of the $c$-axis of the frozen crystals was the same as that of the seed single crystal frost ice. The directions of protrusions which appeared when the supercooled water droplets were incidently frozen were in parallel to the $c$-axis of seed crystal. The reason why the orientation of the $c$-axis of frozen water droplets and the direction of protrusions coincided with the direction of the $c$-axis of seed crystals were considered. And further, the course of the freezing process of the supercooled water droplets nucleated and frozen by contact with a single crystal frost ice was taken by a motordriven camera mounted on a polarizing microscope.
\end{abstract}

\section{Introduction}

Freezing experiments of supercooled water droplets have been carried out by many workers to the present, mainly in connection with the mechanisms of ice crystal multiplication. Dye and Hobbs (1968) and Johnson and Hallett (1968) have made experiments with water droplets about $1 \mathrm{~mm}$ diameter, suspended on a fiber. On the other hand, Brownscombe and Thorndike (1968), Hobbs and Alkezweeny (1968) and Takahashi (1975) made freezing experiments of freely falling water droplets. Gliki and Gromova (1967) used a cinecamera in order to investigate the process of freezing of suspended water drops with a diameter of $500-1,000 \mu \mathrm{m}$.

The process of freezing of supercooled water drops is a key to obtain some information about ice crystal multiplication and the growth mechanisms of the snow crystal, especially, of a stepped column (Magono et al. (1976)). For instance, protrusions which appeared when the supercooled water droplets were frozen suddenly, will produce ice splinters and contribute to a charge generation of frozen droplets (Mason and Maybank (1960), Stott and Hutchinson (1965)).

Pitter and Pruppacher (1973) have shown that water droplets suspended in an air stream, froze as single or poly-crystalline droplets depending on the droplet size and temperature of freezing. Now, it is generally accepted that the polycrystalline snow crystals with shapes of spatial dendrites, radiating assemblages of dendrites and combination of bullets originate from some frozen cloud droplets (Parungo and Weickmann (1973), Kikuchi and Ishimoto (1974)). Thus, it is necessary to investigate the crystallographic orientations of frozen water droplets under various supercooling conditions.

Uyeda and Kikuchi (1976a) using thin sections of frozen water droplets with sizes of 0.4 to $1.7 \mathrm{~mm}$ in diameters showed that an angle be- 
tween the $c$-axes of the neighbouring crystals of the frozen droplets have peaks around $20^{\circ} \sim 30^{\circ}$ and $70^{\circ}$. The authors did not pay an attention to the temperature dependency of the angles of the crystals precisely because most of the droplets were frozen in a temperature range of -17 to $-23^{\circ} \mathrm{C}$. Therefore, it becomes necessary to measure the angles between the $c$-axes of the neighbouring crystals of frozen water droplets classified by the freezing temperature. Furthermore, it is quite essential and fundamental to consider that the nucleation of supercooled cloud droplets is initiated by contact with numerous tiny ice particles floating in the atmosphere.

In this paper, the following experimental results will be described. The first involves the relation between the orientations of seed single crystal ice and frozen water droplets, while the second is concerned with the relation between the orientations of seed crystal and protrusions of the frozen droplet, and the third is concerned with the angles between the $c$-axes of the neighbouring crystals of water droplets frozen by contact with a single crystal ice, and the last study was made to observe the angles between the $c$-axis of frozen water droplet and air bubble layers in the frozen droplet.

\section{Experimental}

The experimental apparatus is shown in Fig. 1. Water droplets of sizes between 0.6 and $1.0 \mathrm{~mm}$ in diameter were made of distilled and de-ionized water and they were inserted by a hypodermic syringe and suspended at the interface of dichloroethane and paraffin liquids in a petri dish which was prepared on the microscope stage. The droplets were cooled in a cold room

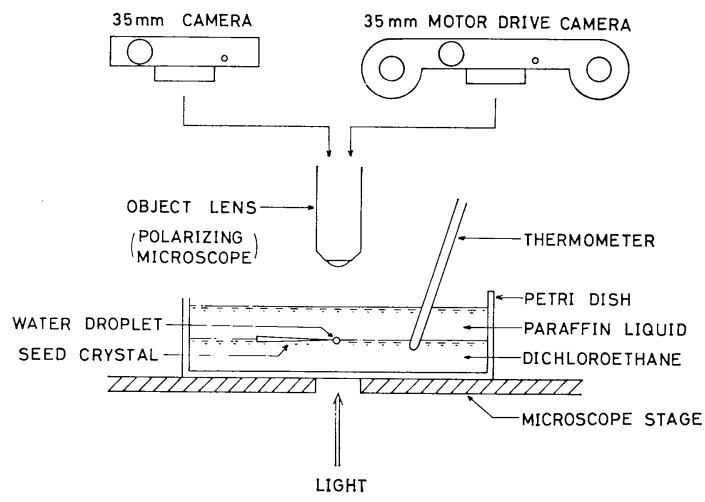

Fig. 1 Schematic figure of the experimental equipment. until a temperature equilibrium was reached between the experimental petri dish and the cold room. Then the droplets were nucleated with a single crystals frost ice of needle type at the desired temperatures. In this experiment, the $c$ axis of the frost crystal was perpendicular to the light direction of microscope. When water droplets were nucleated by frost ice and frozen single crystal ice, the $c$-axis of the frozen droplets was identified by the extinction of the light beam under crossed nicols. On the contrary, when water droplets were frozen into poly-crystalline ice, the angle between the $c$-axes of neighbouring crystals of the poly-crystalline ice was measured in the same manner as described in a previous paper (Uyeda and Kikuchi, (1976a)).

In order to clarify the course of the freezing process of water droplets to single crystal ice, a Nikon $F$ motor drive camera was used as shown in Fig. 1, and continuous photographs were taken at a rate of 2 frames per second under crossed nicols. Thin sections of frozen droplets were made in order to determine the orientation of the $c$-axis of individual crystals of frozen droplets and the directions of the air bubble layers, and the directions were measured using a universal stage.

\section{Results}

The crystallization of frozen water droplets nucleated by a single crystal frost ice changed to the followings depending on freezing temperatures. At a temperature range of -10 to $-15^{\circ} \mathrm{C}$, almost all supercooled water droplets froze into single crystals with certain types of protrusions (Takahashi (1975), (1976)) in spite of the fact that the contact point of seed single crystal ice and the orientations of the $c$-axes of the frozen crystals were the same as that of seed crystal. The orientation of frozen crystals was determined by the extinction position of the light beam. Furthermore, the direction of protrusions, mainly spike type, was in parallel to the $c$-axis of seed crystal and the starting point of protrusion was on the opposite side of the contact point when the $c$-axis of the seed crystal was brought contact in a normal direction to the supercooled droplet surface as shown in Fig. 2(a). On the other hand, when supercooled droplet was brought in contact with the prism plane of the seed crystal, spike type protrusions grew from the surface of frozen droplet in parallel to the seed crystal as shown in Fig. 2(b). In many cases, the position of the protrusion was along a line through the center of 


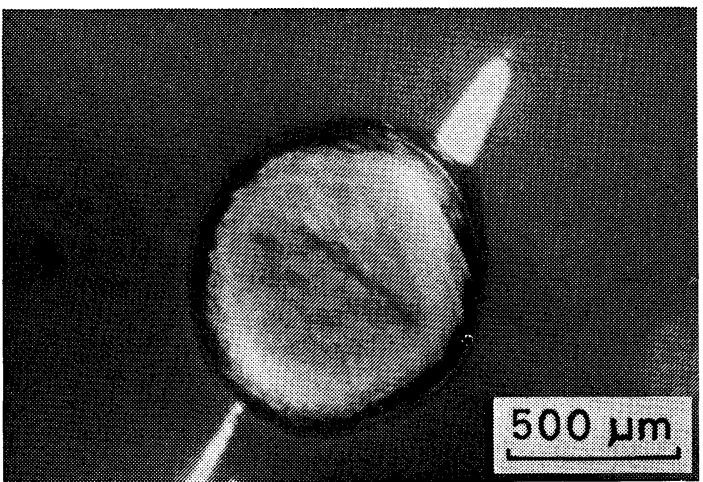

(a)

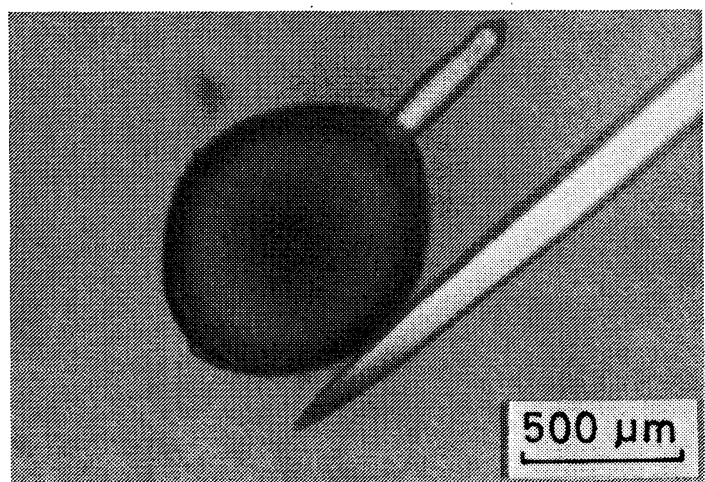

(b)

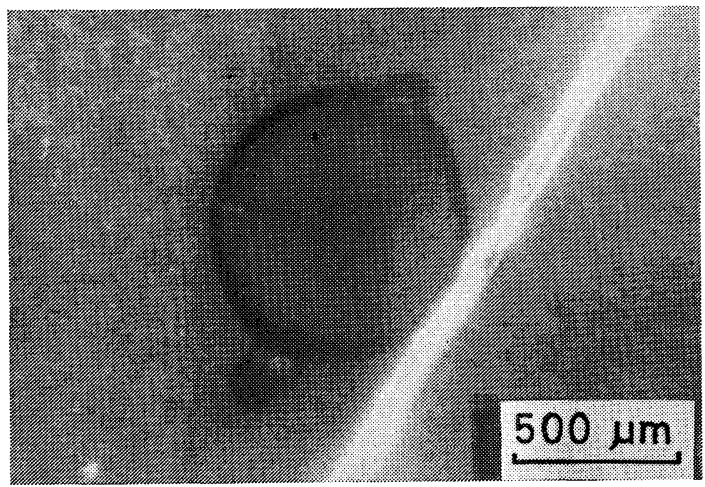

(c)

Fig. 2 Photographs of protrusions which grew from a frozen droplet nucleated by a single crystal of frost ice.

frozen droplets. In 5 out of 27 cases, two protrusions grew from a frozen droplet. In this case, the positions of the protrusions were on both sides of the frozen droplet and the directions thereof were in parallel to the seed crystal and further the two protrusions formed a straight line through the center of the frozen droplets as seen in Fig. 2(c). In this temperature range, cracks on the surfaces of frozen water droplets with protrusion were seen and were found encircling on the surface of the frozen droplets. When the frozen droplets were sliced for preparation of thin sections, the encircled crack became a crack plane and usually the greater part of the plane was in parallel to the basal plane of the frozen droplet, in other words, perpendicular to the protrusion.

In a temperature range of -15 to $-20^{\circ} \mathrm{C}$, of the many water droplets, approximately two thirds present in the experiments froze into poly crystals and the angle between the $c$-axes of neighbouring crystals had a peak around $20^{\circ}$ as shown by the crossed marks connected with solid lines in Fig. 3. However, the angle between the $c$-axes of crystals of frozen water droplets and the seed crystal was not clear because the frozen droplets and the seed crystals were separated from each other when they are picked up by a tweezers from the petri dish for the preparation of thin sections.

In a temperature range of -20 to $-25^{\circ} \mathrm{C}$, the greater part of water droplets froze into poly crystals and the angles between the $c$-axes of the neighbouring crystals had two peaks around $20^{\circ}$

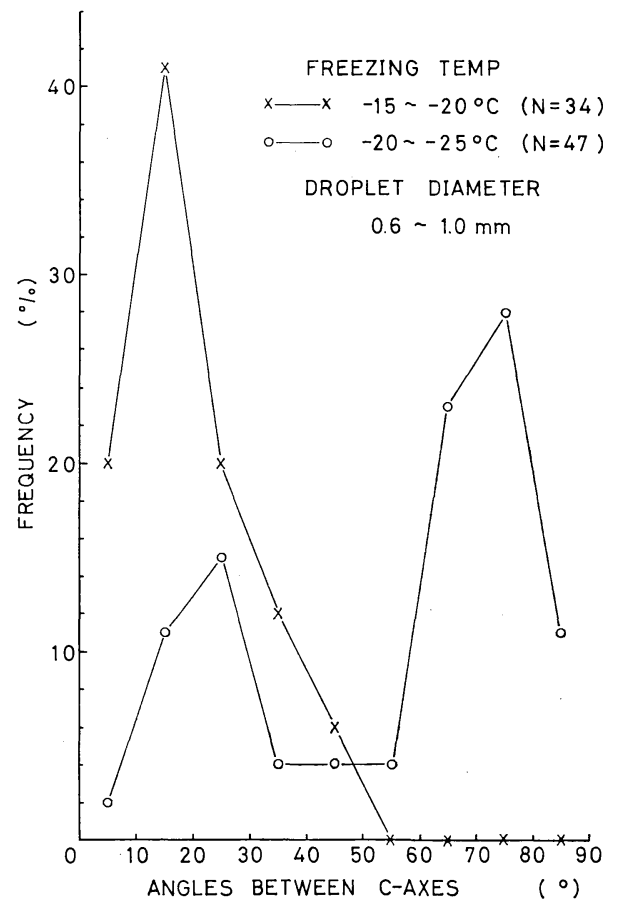

Fig. 3 Frequency distributions of the angles between the $c$-axes of neighbouring crystals of frozen water droplets at temperature ranges of -15 to $-20^{\circ} \mathrm{C}$ and -20 to $-25^{\circ} \mathrm{C}$. 


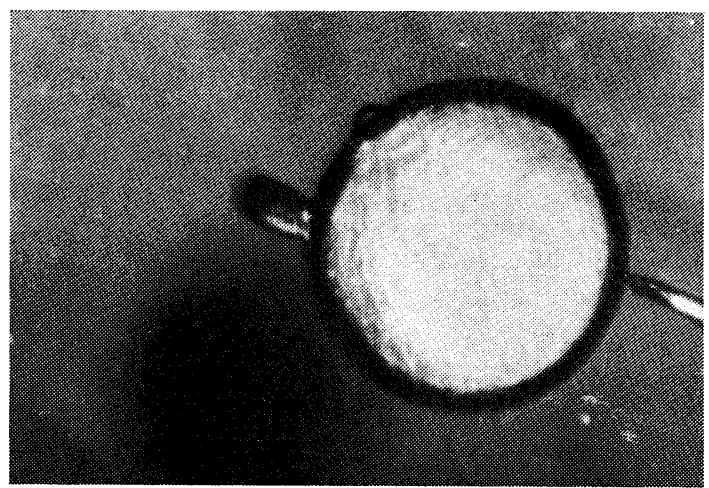

(a)

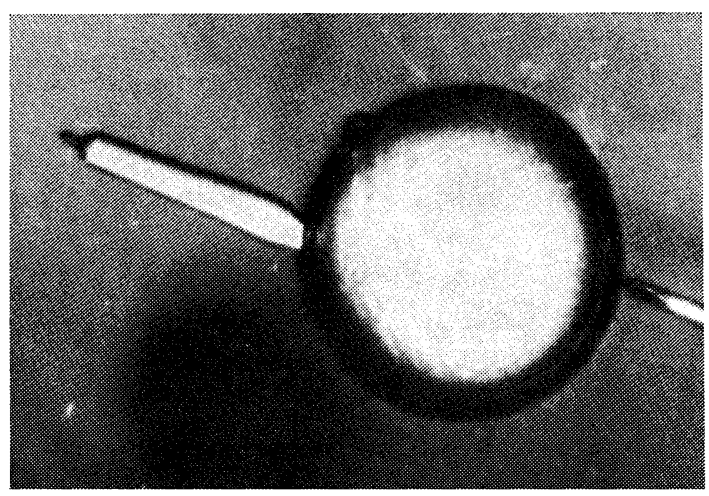

(c)

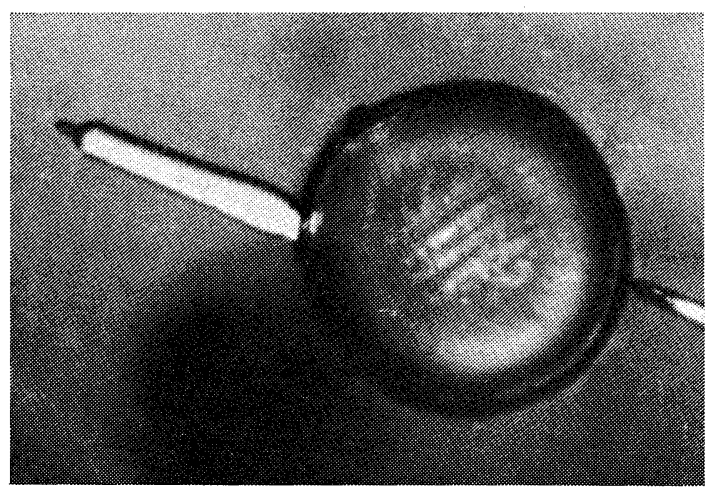

(e)

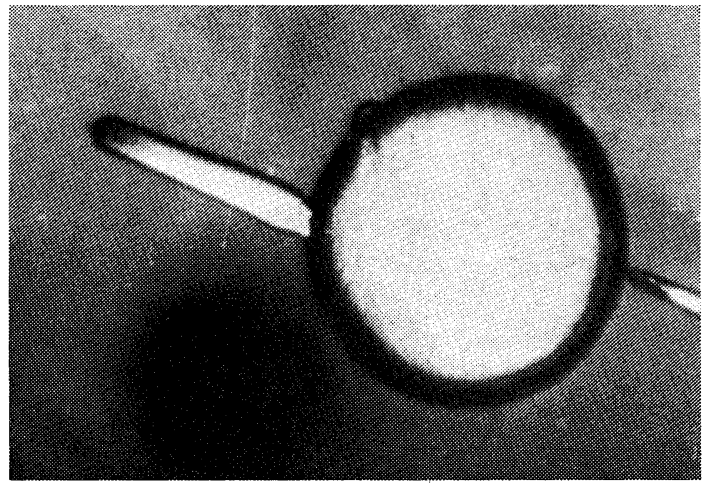

(b)

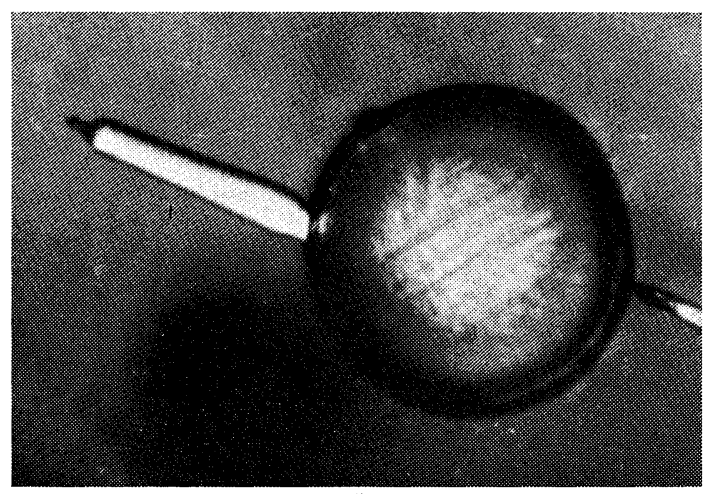

(d)

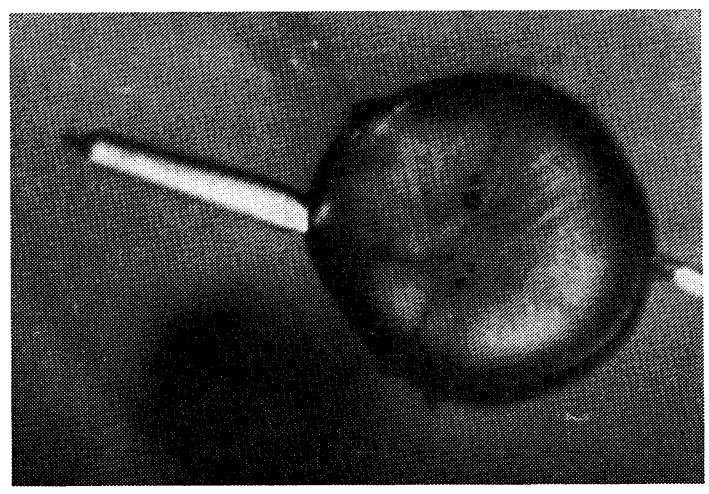

(f)

Fig. 4 Freezing process of a supercooled water droplet nucleated by a single crystal of frost ice.
(a) Beginning of freezing
(b) 0.5 seconds later from (a)
(c) 1.0 seconds later from (a)
(d) 2.0 seconds later from (a)
(e) 2.5 seconds later from (a)
(f) 14.0 seconds later from (a). Air bubbles ejected into liquid through the cracks from inside of the droplet are seen.


and $70^{\circ}$ as shown by the white circles connected with solid lines in Fig. 3. The peak around $70^{\circ}$ was more predominant than that around $20^{\circ}$. The peak around $70^{\circ}$ is quite important in considering the angle between branches of poly-crystalline snow crystals; for example, crystals such as radiating assemblages of dendrites and combination of bullets (Lee (1972), Uyeda and Kikuchi (1976b), Kobayashi et al. (1976)). In the previous experiment by the authors (Uyeda and Kikuchi, (1976a)), they emphasized two remarkable peaks around $20^{\circ}$ to $30^{\circ}$ and $60^{\circ}$ to $80^{\circ}$ which were seen irrespective of the cooling rates. Combined with the results of our previous experiments and the temperature ranges of -15 to $-20^{\circ} \mathrm{C}$ and -20 to $-25^{\circ} \mathrm{C}$ in this experiment, it is considered that the peak of $20^{\circ}$ to $30^{\circ}$ in the previous one is affected by relatively warmer temperatures in a range of -17 to $-23^{\circ} \mathrm{C}$. In this temperature range, the $c$-axes of crystals of frozen water droplets appeared to be different from that of seed crystals as far as they were examined by extinction of polarization light beam in a petri dish.

As mentioned above, it was recognized that the crystallization of frozen water droplets nucleated by single crystal frost ice depended on the freezing temperature. And then, in order to obtain more detailed information on the freezing processes of the supercooled water droplets a motor drive camera mounted on a polarizing microscope was used. The temperature in this experiment was selected to fall in a range between -10 and $-15^{\circ} \mathrm{C}$, because the freezing period of supercooled water droplets in this temperature range was relatively longer than that of lower temperatures as compared to this range. This is well known hitherto as reported by Hallett (1964), Macklin and Ryan (1968). The results on 32 water droplets with the motor drive camera were as follows. As shown in Fig. 4, as soon as the seed crystal comes in contact with the surface of a supercooled water droplet, a thin shell on the surface of the droplet was formed, and certain kinds of protrusions appeared immediately after the thin shell was formed as seen in Fig. 4(a). The tip of the protrusion was not crystalline but was still water at this time, and at 0.5 seconds later, the protrusion increased in length in the same direction and became a long spike which formed one of protrusions (Fig. 4(b)). Moreover, after 1 second from the onset of freezing, a tiny second protrusion appeared at the tip of the long spike as shown in Fig. 4(c). The crystallization of this droplet progressed inward as shown by a dark ring in the droplet as seen in Fig. 4(c) to 4(e). Cracks were seen through the droplet with the crack planes in parallel with the basal plane when the freezing was completed, and air bubbles were ejected into the liquid through the cracks from the inside of the droplet (Fig. 4(f)). Charge generation due to the splintering by sudden freezing of the supercooled water droplets was reported by many workers, (Mason and Maybank (1960), Stott and Hutchinson (1965), Iwabuchi and Magono (1975)), however, another mechanism of charge generation will be expected from the result of ejection of relatively large air bubbles during freezing of supercooled water droplets. Fortunately the phenomenon of ejection of air bubbles was ascertained as the experiment was carried out in the liquid. In some cases, the direction of the second protrusion was shifted from that of the first protrusion.

Beneath the surface of frozen water droplets, several tens layers of numerous tiny air bubbles were seen, especially when the freezing of water droplets was proceeding as seen from (c) to (f) in Fig. 4 as mentioned by Gliki and Gromova (1967). The layers of air bubbles do not seem to be in parallel with the basal plane, although they are usually thought to be in parallel with the basal plane. Then the angle between the $c$ axis of the frozen droplet which was nucleated by a single crystal of frost ice and the layers on which air bubbles lay was measured under a polarizing microscope after making thin sections with special regard to the water droplets frozen in a temperature range of -10 to $-15^{\circ} \mathrm{C}$. The results show that there was a prominent peak around $60^{\circ}$ which differs from the results of Gliki and Gromova (1967) and Takahashi (1976). However, we did not have any information concerning this peak, $60^{\circ}$, till the present.

\section{Concluding remarks}

The authors have shown in their previous paper (1976a) that the angles between the $c$-axes of neighbouring crystals of frozen water droplets have peaks around $20^{\circ}$ to $30^{\circ}$ and $60^{\circ}$ to $80^{\circ}$, although they did not pay sufficient attention to the temperature dependency of the angle between the crystals at that time. Hence, the temperature dependency of the angle between the $c$-axes of neighbouring crystals of frozen water droplets was investigated in this experiment. In a temperature range of -15 to $-20^{\circ} \mathrm{C}$, the peak of the angles between the $c$-axes of neighbouring 
crystals was around $20^{\circ}$, on the other hand, there were two peaks around $20^{\circ}$ and $70^{\circ}$ in a temperature range of -20 to $-25^{\circ} \mathrm{C}$. Considering these results as compared with our previous paper (1976a), the peak around $20^{\circ}$ was considered to be affected by relatively warmer temperatures above $-20^{\circ} \mathrm{C}$. As well know to date, natural snow crystals grown at the air temperature below $-20^{\circ} \mathrm{C}$, for example, crystals such as radiating assemblages of dendrites and combination of bullets had a prominent peak around $70^{\circ}$ of the angles between the $c$-axes of the neighbouring branches (Lee (1972), Uyeda and Kikuchi (1976b) and Kobayashi et al. (1976)). The peak around $70^{\circ}$ appeared in this experiment at a temperature range of -20 to $-25^{\circ} \mathrm{C}$ which coincided with the results of their observations. Although in the case of water droplets frozen at a temperature range of -20 to $-25^{\circ} \mathrm{C}$ the peak around $20^{\circ}$ between the $c$-axes of neighbouring crystals appeared together with the peak around $70^{\circ}$ and further in the case of water droplets frozen at a temperature range of -15 to $-20^{\circ} \mathrm{C}$, the peak around $20^{\circ}$ appeared alone, and a peak around $20^{\circ}$ was not observed in natural poly-crystalline snow crystals. In the previous paper the reasons why the peak around $20^{\circ}$ did not appear in snow crystals were discussed. The reasons were surmised to be as follows; (1) recrystallization of frozen cloud droplets during their descent, (2) restriction of diffusion vapour flux to small areas on the droplets and (3) the effect of the small size of natural cloud droplets. Considering the results of this experiment, it may be concluded that the angle of $20^{\circ}$ appeared when the freezing was initiated under conditions of relatively warmer temperature than $-20^{\circ} \mathrm{C}$. In the crystal shapes of radiating assemblage of dendrites and combination of bullets, as they begin their growth initially under temperature conditions lower than $-20^{\circ} \mathrm{C}$, generally the angle between neighbouring crystals frozen from supercooled cloud droplets will not take a $20^{\circ}$ angle each other. If any of them take an angle of $20^{\circ}$, the angle would be diminished during their descent owing to the reasons described previously. Recently, Kikuchi and Magono (1977) observed that a number of supercooled cloud droplets impacted and froze on the surface of natural falling snow crystals and that a number of grains of ice were polycrystalline and the angle between neighbouring crystals had relatively large angles when viewed under a polarizing microscope.

At a temperature range of -10 to $-15^{\circ} \mathrm{C}$, almost all of the supercooled water droplets froze into single crystals and the orientation of the $c$ axis of the frozen crystals was the same as that of the seed crystal. And further the directions of protrusions which appeared when the supercooled water droplets were incidently frozen were in parallel to $c$-axis of the seed crystal. The reason why the orientation of the $c$-axis of frozen water droplets and the direction of protrusions coincided with the direction of the $c$-axis of seed crystals is considered to be as follow. In the early stage of freezing when the water droplet was brought in contact with the pointed end of the seed crystal, a thin shell of ice formed on the (a)
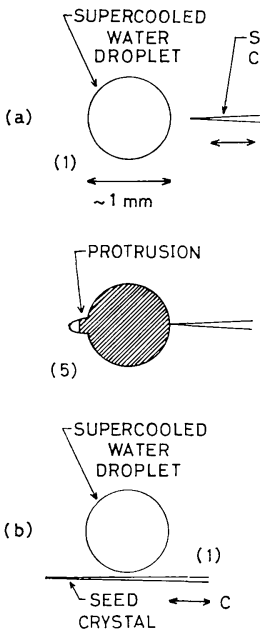

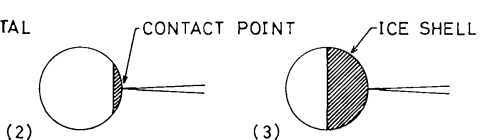

(3)
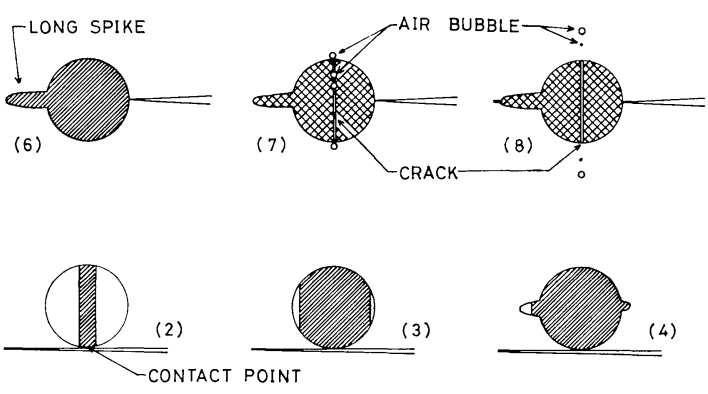

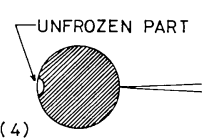

(4)

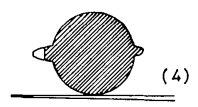

Fig. 5 Schematic figures of the freezing processes of supercooled water droplets nucleated by a single crystal of frost ice. 


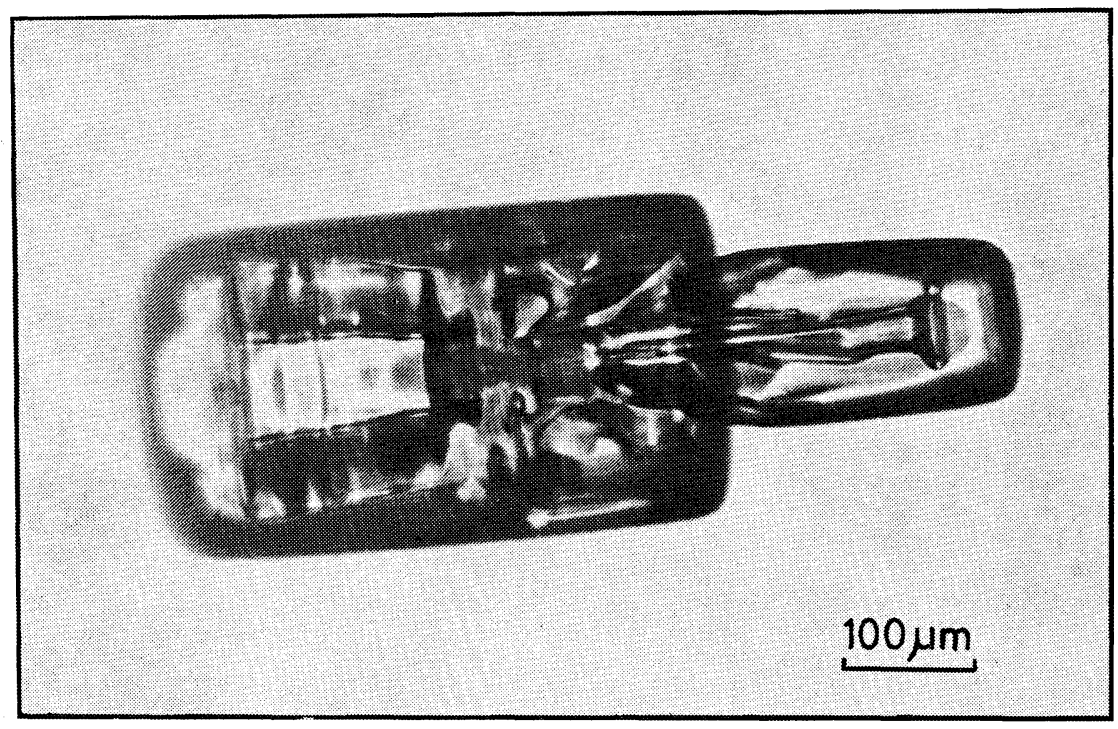

Fig. 6 An example of a natural snow crystal of stepped column type observed at Syowa Station, Antarctica, 1968.

surface of the water droplet in the experiment ran to the opposite side of contact point and the unfrozen part was left on the opposite side. And next, the unfrozen water inside of the ice shell was pushed out from this part. In this manner, a long spike was formed. A series of the freezing process is illustrated in Fig. 5(a). At times, a second small protrusion appeared from the top of the long spike. On the contrary, when a water droplet was brought in contact with the prism plane of seed crystal, two protrusions appeared on both sides in parallel to the seed crystal in some cases. This result will be explained by the difference of growth rates of the $c$-axes, that is to say, the growth rate of ice sheet in parallel to the $c$-axis is slower than that perpendicular to the $c$ axis as shown in the experiments by Jackson et al. (1968) and Macklin and Ryan (1968). Protrusions on both sides of the experimental water droplet are formed from two unfrozen parts as illustrated in Fig. 5(b). Although the freezing temperature and droplet size are different, these mechanisms are applicable to the explanation of the formation of stepped column type ice crystal as shown in Fig. 6 and which was produced experimentally by Magono et al. (1976). At the last stage of freezing of the water droplets, cracks appear through the surface of the droplets as shown in Fig. 4(f). Then a number of air bubbles are ejected out through the cracks from the inside of the droplet. The ejection of air bubbles will contribute to the charge generation when the supercooled water droplets were frozen incidentally. Although it has been reported that the shattering was examined throughout the freezing experiments (Takahashi (1975)), no shattering phenomena were found in the present experiment. It was considered the reason why no shattering was present in this experiment because the freezing experiment was performed at the interface of two liquids. Air bubble layers were seen in the frozen water droplets. The air bubble layers were not in parallel to the basal plane in the present experiment differing from the results of Gliki and Gromova (1967) and Takahashi (1976). Therefore it may be concluded that it is difficult to determine the orientation of the $c$-axes of small frozen water droplets by measuring the direction of air bubble layers.

\section{Acknowledgements}

The authors express their hearty thanks to Prof. C. Magono, Department of Geophysics, Hokkaido University, for his discussions throughout the course of this study. A part of the expense of this study, especially, the equipment used for this experiment was defrayed by the Special Funds given to Kikuchi at 1972 from the Ito Science Fundation. 


\section{References}

Brownscombe, J. L. and N. S. C. Thorndike, 1968: Freezing and shattering of water droplets in free fall. Nature, 220, 687-689.

Dye, J. E. and P. V. Hobbs, 1968: The influence of environmental parameters on the freezing and fragmentation of supercooled water drops. $J$. Atmos. Sci., 25, 82-96.

Gliki, N. V. and T. N. Gromova, 1967: Simplest types of the crystallization of supercooled drops of water. Soviet Phys. Crystallography, 11, 672679.

Hallett, J., 1964: Experimental studies of the crystallization of supercooled water. J. Atmos. Sci., 21, 671-682.

Hobbs, P. V. and A. J. Alkezweeny, 1968: The fragmentation of freezing water droplets in free fall. J. Atmos. Sci., 25, 881-888.

Iwabuchi, T. and C. Magono, 1975: A laboratory experiment on the freezing electrification of freely falling water droplets. J. Meteor. Soc. Japan, 53, 393-401.

Jackson, K. A., D. R. Uhlamann and J. D. Hunt, 1967: On the nature of crystal growth from the melt. J. Crystal Growth, 1, 1-36.

Johnson, D. A. and J. Hallett, 1968: Freezing and shattering of supercooled water drops. Quart. J. Roy. Meteor. Soc., 94, 468-492.

Kikuchi, K. and K. Ishimoto, 1974: Role of frozen cloud droplets on the growth of snow crystals of certain shapes. J. Fac. Sci., Hokkaido Univ., Ser. VII, 4, 69-80.

$\longrightarrow$, and C. Magono, 1977: Paper presented at Spring Meeting of the Meteor. Soc. Japan in May at Tokyo.

Kobayashi, T., Y. Furukawa, T. Takahashi and H. Uyeda, 1976: Cubic structure models at the junction in polycrystalline snow crystals. J. Crystal Growth, 35, 262-268.
Lee, C. W., 1972: On the crystallographic orientation of spatial branches in natural polycrystalline snow crystals. J. Meteor. Soc. Japan, 50, 171179.

Macklin, W. C. and B. F. Ryan, 1968: Growth velocities of ice in supercooled water and aqueous solution. Phil. Mag., 14, 83-87.

Magono, C., S. Fujita and T. Taniguchi, 1976: Shapes of single ice crystals originated from frozen cloud droplets. Preprint Volume International Conference on Cloud Physics, Boulder, 103-105.

Mason, B. J. and J. Maybank, 1960: The fragmentation and electrification of freezing water drops. Quart. J. Roy. Meteor. Soc., 90, 176-185.

Parungo, F. P. and H. K. Weickmann, 1973: Growth of ice crystals from frozen cloud droplets. Beit. zur Phys. Atmos., 46, 289-304.

Pitter, R. L. and H. R. Pruppacher, 1973: A wind tunnel investigation of freezing of small water drops falling at terminal velocity in air. Quart. J. Roy. Meteor. Soc., 99, 540-550.

Stott, D. and W. C. A. Hutchinson, 1965: The electrification of freezing water drops. Quart. J. Roy. Meteor. Soc., 91, 80-85.

Takahashi, C., 1975: Deformation of frozen water drops and their frequencies. J. Meteor. Soc. Japan, 53, 402-411.

, 1976: Relation between the deformation and the crystalline nature of frozen water drops. J. Meteor. Soc. Japan, 54, 448-453.

Uyeda, H. and K. Kikuchi, 1976a: On the orientation of the principal axis of frozen water droplets. J. Meteor. Soc. Japan, 54, 267-275.

- , and 1976b: Remeasurement of the axial angle between spatial branches of natural polycrystalline snow crystals. J. Fac. Sci., Hokkaido Univ., Ser. VII, 5, 21-28.

\title{
単結晶永で凍結させた過冷却水滴の凍結実験
}

\author{
上田博・菊地 勝 弘 \\ 北海道大学理学部地球物理学教室
}

凍結水滴の隣合った結晶相互の主軸のなす角度の温度依存性を調べるために, 直径 $0.6 \sim 1.0 \mathrm{~mm}$ の過冷却水滴を $-10 \sim-15^{\circ} \mathrm{C},-15 \sim-20^{\circ} \mathrm{C},-20 \sim-25^{\circ} \mathrm{C}$ の $3 つ の$ 温度範囲で, 単結晶の霜を用いて凍結させた。

温度範囲 $-15 \sim-20^{\circ} \mathrm{C}$ では，隣合った結晶の主軸のなす角度のピークはほぼ $20^{\circ}$ 付近にあったが，一20〜 $-25^{\circ} \mathrm{C}$ の温度範囲では $20^{\circ}$ と $70^{\circ}$ にピークが認められた。このことから先の論文 (Uyeda and Kikuchi (1976a)) で得られた $20^{\circ}$ 付近のピークは $-17 \sim-23^{\circ} \mathrm{C}$ の温度範囲の内でも比較的暖かい温度で凍結したものと 結論された。一方 $-20 \sim-25^{\circ} \mathrm{C}$ の温度範囲で得られた $70^{\circ}$ 付近のピークは $-20^{\circ} \mathrm{C}$ 以下の温度で成長する雪結 晶すなわち，放射樹枝や砲弾集合の隣合った結晶の主軸のなす角度を測定した従来をでの結果と一致していた。 $-10 \sim-15^{\circ} \mathrm{C}$ の温度範囲の実験では過冷却水滴の大部分は単結晶に凍り，その結晶の主軸の方向は凍結させるのに 使用した単結晶の霜の主軸の方向と一致していた。凍結する時に現われる protrusion (突起) の方向もまた使用し 
た単結晶の方向と一致していた。凍結した水滴の主軸の方向が, また protrusion の方向が, 使用した単結晶の主軸 の方向と何故一致するかの考察が行われた。

さらにまた，このような方法で涷らされた時の一連の過程が偏光顕微鏡下でモータードライブカメラの駒撮りによ って明らかにされた。 